\title{
PENGARUH DOSIS BLEACHING EARTH DAN WAKTU PEMUCATAN CRUDE PALM OILYANG BERVARIASI DETERIORATION OF BLEACHABILITY INDEX (DOBI) TERHADAP MUTU PRODUK
}

\section{THE EFFECTS OF BLEACHING EARTH DOSAGE AND TIME FOR BLEACHING TIME OF CRUDE PALM OIL VARIED DETERIORATION OF BLEACHABILITY INDEX (DOBI) TO THE QUALITY OF PRODUCT}

\author{
Hasrul Abdi Hasibuan ${ }^{1)^{*}}$, Lia Afriana ${ }^{2)}$ dan Debby Tamba ${ }^{2)}$ \\ ${ }^{1)}$ Kelompok Peneliti Pengolahan Hasil dan Mutu, Pusat Penelitian Kelapa Sawit, \\ Jl. Brigjend Katamso No. 51, Medan 20158, Indonesia \\ E-mail: hasibuan_abdi@yahoo.com \\ ${ }^{2)}$ Jurusan Kimia, Universitas Negeri Medan, Medan, Indonesia \\ Makalah: Diterima 3 Mei 2016; Diperbaiki 2 Desember 2016; Disetujui 20 Desember 2016
}

\begin{abstract}
Deterioration of bleachability index (DOBI) is one of the parameters in the refining process, to meet the quality of commercial crude palm oil (CPO); Miixing between high quality $C P O$ and low quality CPO sometimes were undertaken. This study was conducted to assess the effect of dose of bleaching earth (BE) and time of bleaching process of various CPO quality, especially CPOs that had different DOBIs. The raw materials used were CPO with DOBIs of 0.65 to 4.80 which obtained from different raw materials, namely of fresh fruit bunches (FFB), palm oil mill (POM), waste from POM, and CPO from FFB heated at $120^{\circ} \mathrm{C}$ (during 30 and 60 minutes) and mixed with low quality $C P O$ (ratio of 6:4 and 1:9). CPOs were bleached using BE doses of 0.5\%, $1.0 \%, 2.5 \%$, and $2 \%$ and time for $15,30,45$, and 60 minutes. The results obtained from preparation of raw materials were CPO with DOBI of 3.9 and 4.8 (CPO from FFB 1 and 2), 1.4 and 2.68 (CPO from POM 1 and 2) and 0.85 (CPO from waste POM 2) as well as 2.5 and 0.65 (heating) and 2.92 and 1.52 (mixing). The warming of CPO caused colour, carotene, and water content decreased, while free fatty acids (FFA) and peroxide value $(P V)$ increased. The more CPO low quality mixed to CPO high quality caused carotene and DOBI decreased while colour, moisture content, FFB, and PV increased. The results of bleaching showed that increasing time and dose of BE caused colour, carotene, DOBI, and water contents decreased, while FFA increased. PV decreased with increasing doses of $B E$ and for 30 minutes $P V$ decreased then increased with increasing time. Bleaching process of CPO from mixing between high quality CPO and low quality CPO might increase FFA, despite the mixture resulted CPO had high DOBI. This would impact on the deodorization process.
\end{abstract}

Keywords: crude palm oil, bleaching, bleaching earth, deterioration of bleachability index

\section{ABSTRAK}

Deterioration of bleachability index (DOBI) merupakan salah satu parameter dalam proses refining, untuk memenuhi kualitas CPO komersial, ada kalanya dilakukan pencampuran antara CPO bermutu baik dan CPO bermutu rendah. Penelitian ini dilakukan untuk mengkaji pengaruh dosis bleaching earth (BE) dan waktu proses pemucatan berbagai mutu CPO, khususnya CPO yang memiliki nilai DOBI berbeda. Bahan baku yang digunakan adalah CPO DOB I0, 65-4,80 yang diperoleh dari bahan baku berbeda yaitu dari tandan buah segar (TBS), pabrik kelapa sawit (PKS), limbah PKS serta CPO dari TBS yang dipanaskan pada $120^{\circ} \mathrm{C}$ (selama 30 dan 60 menit) dan dicampur dengan CPO mutu rendah (rasio 6:4 dan 1:9). Pemucatan CPO dilakukan menggunakan dosis BE 0,$5 ; 1,0 ; 1,5$ dan 2,0\% dan waktu pemucatan 15; 30; 45 dan 60 menit. Hasil preparasi bahan diperoleh CPO dengan nilai DOBI 3,9 dan 4,8 (CPO dari TBS 1 dan 2), 1,4 dan 2,68 (CPO dari PKS 1 dan 2) dan 0,85 (CPO dari limbah PKS 2) serta 2,5 dan 0,65 (pemanasan) dan 2,92 dan 1,52 (pecampuran). Pemanasan CPO menyebabkan warna, karoten, dan kadar air menurun sedangkan asam lemak bebas (ALB) dan bilangan peroksida (PV) meningkat. Semakin banyak CPO mutu rendah dicampur ke CPO mutu tinggi juga menyebabkan karoten dan DOBI menurun sedangkan warna, kadar air, ALB dan PV meningkat. Hasil pemucatan menunjukkan bahwa meningkatnya waktu dan dosis BE menyebabkan warna, karoten, DOBI dan kadar air menurun sementara ALB meningkat. PV menurun dengan meningkatnya dosis BE, selama waktu 30 menit PV juga menurun namun meningkat kembali dengan meningkatnya waktu. Proses pemucatan yang menggunakan CPO hasil pencampuran CPO mutu tinggi dan CPO mutu rendah dapat meningkatkan ALB, meskipun CPO hasil campuran tersebut memiliki nilai DOBI tinggi. Hal tersebut berdampak pada proses deodorisasi lebih lanjut.

Kata kunci: crude palm oil, pemucatan, bleaching earth, deterioration of bleachability index

\section{PENDAHULUAN}

Rafinasi merupakan suatu proses untuk memurnikan crude palm oil (CPO) melalui 3 tahapan yaitu degumming, bleaching dan deodorisasi. Setiap tahapan bertujuan untuk menghilangkan gum, menyerap warna dan logam berat, memucatkan dan menghilangkan warna dan air. Bleaching merupakan tahapan yang cukup 
menentukan mutu minyak goreng yang dihasilkanmeliputi warna kuning pucat dan tidak mengandung logam berat (Morad et al., 2006; Hasibuan dan Nuryanto, 2011; Hasibuan, 2016). Bleaching CPO dilakukan dengan menggunakan tanah pemucat/bleaching earth (BE) seperti lempung terpilar, bentonit, karbon aktif, alumina, silika dan lain-lain (Nursulihatimarsyila et al., 2012; Ejikeme et al., 2013). Jumlah dosis BE disesuaikan dengan mutu CPO, salah satunya adalah nilai deterioration of bleachability index (DOBI). DOBI merupakan salah satu parameter mutu CPOuntuk mengukur tingkat kerusakan minyak yang disebabkan oleh oksidasi, nilai DOBI rendah mengindikasikan naiknya kandungan produk oksidasi sekunder $(\mathrm{Ng}$ dalam Jusoh et al., 2013).

Umumnya, proses bleaching dilakukan dengan menggunakan $\mathrm{BE}$ sebanyak $0,5-2 \%$ dari berat $\mathrm{CPO}$ dan suhu $95-105^{\circ} \mathrm{C}$ selama 30 menit. Apabila dosis BE kurang mampu memucatkan CPO maka proses deodorisasi lebih lanjut menjadi terkendala sehingga membutuhkan energi lebih tinggi dan waktu proses lebih lama. Penggunaan BE akan semakin banyak apabila nilai DOBI rendah sehingga biaya produksi tinggi (Morad et al., 2006; Gibon et al., 2009; Hasibuan, 2016).

CPO yang memiliki nilai DOBI sebesar 2,2 dapat dikategorikan bermutu baik (Hasibuan, 2016). Siahaan et al., 2009 dan Hasibuan, 2012 melaporkan nilai DOBI pada CPO yang dihasilkan oleh pabrik kelapa sawit (PKS) di Indonesia masing-masing sebesar 0,90-2,99 dan 0,44-2,87. Rendahnya nilai DOBI pada CPO disebabkan oleh kematangan buah, waktu pengolahan buah, kondisi proses pengolahan, kontaminasi, penyimpanan dan distribusi CPO yang tidakstandar (Onwuka dan Akaerue, 2006; Panjaitan et al., 2009; Akmazillah et al., 2011; Hasibuan dan Ramadona, 2012; Subramaniam et al., 2013; Jusoh et al., 2013). Penurunan nilai DOBI di PKS diakibatkan oleh pemanasan yang berlebihan dan proses pengutipan kembali minyak (recovery) dari limbah di PKS yang dicampur ke dalam CPO mutu baik (Hasibuan dan Ramadona, 2012). Hal ini menyebabkan senyawa karoten terdegradasi dan menyebabkan nilai DOBI menjadi rendah. Hasibuan (2016) melaporkan bahwa kadar karoten memiliki korelasi searah dan kuat terhadap DOBI, artinya jika kadar karoten tinggi maka nilai DOBI juga tinggi.

Untuk memenuhi kualitas CPO khususnya nilai DOBI, ada kalanya dilakukan pencampuran antara CPO mutu baik (DOBI tinggi) dan CPO mutu rendah (DOBI rendah). Adanya usaha untuk memanipulasi nilai DOBI tersebut akan berdampak pada mutu lainnya seperti asam lemak bebas (ALB), bilangan peroksida (PV), kadar karoten, air dan warna (Hasibuan dan Ramadona, 2012). Oleh karena itu, penelitian ini dilakukan untuk mengkaji pemucatan CPO yang memiliki nilai DOBI berbeda menggunakan $\mathrm{BE}$ dan waktu yang bervariasi terhadap mutu produknya meliputi warna, kadar karoten, DOBI, ALB, kadar air dan PV.

\section{BAHAN DAN METODE}

\section{Bahan}

Bahan yang digunakan adalah tandan buah segar (TBS) sebanyak 2 buah yang diperoleh dari Kebun Adolina, Perbaungan, Sumatera Utara. TBS 1 merupakan buah lewat matang (buah jatuh di piringan > 40 butir) dan TBS 2 merupakan buah tepat matang (buah jatuh di piringan 5-10 berondolan). CPO bermutu rendah (nilai DOBI < 2) dan bermutu tinggi (nilai DOOBI > 2) diperoleh dari 2 pabrik kelapa sawit (PKS) serta CPO limbahdari limbah PKS di Sumatera Utara. Bleaching earth (BE) diperoleh dari PT. Astra Agro Lestari. Tbk, Tanjung Morawa, Medan. Bahan-bahan kimia untuk analisa seperti heksan p.a, KOH p.a, indikator fenolftalen p.a dan natrium tiosulfat p.a diperoleh dari E. Merck, Jerman. Bahan kimia lainnya seperti alkohol teknis industrial grade dari supplier lokal.

\section{Metode}

Persiapan Bahan Baku

Bahan baku dipersiapkan dengan cara yaitu: a. CPO dari PKS diambil di tangki timbun di PKS 1 dan PKS 2 (CPO PKS 1 dan CPO PKS 2).

b. CPO limbah diperoleh dari limbah PKS 2 ( $C P O$ limbah).

c. CPO dari TBS diperoleh dengan cara ekstraksi secara sederhana dengan mengkukus TBS 1 dan TBS 2 dalam wadah berisi air dan dipanaskan menggunakan kompor pada suhu air mendidih selama 2 jam. Setiap TBS yang telah direbus dipisahkan antara mesokarp dan biji. Minyak pada mesokarp diekstraksi menggunakan alat press dan selanjutnya disentrifugasi untuk memisahkan antara minyak dan kotoran berupa air dan non oil suspended (NOS) (CPO TBS 1 dan CPO TBS 2).

d. CPO TBS 1 dipanaskan pada suhu $120{ }^{\circ} \mathrm{C}$ selama 30 menit (PM 1) dan 60 menit (PM 2)

e. CPO TBS 1 dicampur dengan CPO bermutu rendah dari PKS 1 pada rasio 60:40 (PC 1) dan 10:90 (PC 2).

\section{Percobaan I: Pengaruh waktu pemucatan}

Sebanyak 8 sampel CPO bervariasi DOBI di-degumming menggunakan asam fosfat tara pangan dengan konsentrasi $0,15 \%$ dari berat CPO dan dipanaskan pada $95^{\circ} \mathrm{C}$ selama 15 menit. CPO yang telah di-degumming selanjutnya dipucatkan menggunakan dosis BE $1 \%$, suhu $95^{\circ} \mathrm{C}$ dan waktu 15; 30; 45; 60 menit.

\section{Percobaan II: Pengaruh dosis BE}

Sebanyak 8 sampel CPO bervariasi DOBI di-degumming menggunakan asam fosfat tara pangan dengan konsentrasi $0,15 \%$ dari berat CPO dan dipanaskan pada $95^{\circ} \mathrm{C}$ selama 15 menit.CPO yang telah di-degumming selanjutnyadipucatkan 
pada suhu $95^{\circ} \mathrm{C}$ selama 30 menit dan dosis $\mathrm{BE} 0$; 0,$5 ; 1,0 ; 1,5 ; 2,0 \%$.

\section{Analisa Mutu}

Setelah proses pemucatan, BE dipisahkan dengan penyaringan menggunakan kertas saring Whatman No. 1. Produk yang dihasilkan disebut sebagai bleached palm oil (BPO) dan dianalisa meliputi warna, kadar karoten, DOBI, ALB, kadar air dan PV dengan menggunakan metode standar MPOB Test Method (MPOB, 2004).

\section{HASIL DAN PEMBAHASAN}

\section{Mutu Bahan Baku CPO}

Hasil preparasi bahan baku diperoleh CPO dengan nilai DOBI 3,9 dan 4,8 (CPO dari TBS 1 dan 2), 1,4 dan 2,68 (CPO dari PKS 1 dan 2) dan 0,85 (CPO dari limbah PKS 2) serta 2,5 dan 0,65 (pemanasan) dan 2,92 dan 1,52 (pencampuran) (Tabel 1). Tabel 1 menunjukkan bahwa seluruh CPO yang digunakan cukup representatif untuk mengkaji proses pemucatannya. Selanjutnya, proses pemucatan dilakukan hanya menggunakan 8 bahan baku seperti yang tercantum pada Tabel 1 kecuali CPO dari PKS 1.

Pengaruh Waktu Bleaching dan Dosis BE terhadap Mutu Bleached Palm Oil (BPO)

Tujuan proses bleaching adalah memucatkan warna dan menyerapsebagian warna, gum dan logam yang terkandung pada CPO.Menurut Morad et al. (2006) bahwa partikel warna selama bleaching ada di dalam larutan minyak atau dalam bentuk koloid yang reaksinya terjadi pada permukaan BE. Pada penelitian ini selain mengkaji perubahan warna akibat proses bleaching juga melihat mutu lainnya meliputi kadar karoten, DOBI, ALB, kadar air dan PV.

Warna CPO mengalami penurunan setelah dilakukan proses bleaching dan terus menurun dengan meningkatnya waktu bleaching (Tabel 2). Morad et al. (2006) juga melaporkan hal yang sama dan penurunan warna ini disebabkan oleh senyawa karoten terdegradasi dan sebagian terjerap ke dalam BE. BE memiliki pori-pori yang cukup luas yang dapat menyerap warna dan senyawa-senyawa lain (Hasibuan dan Nuryanto, 2011). Setelah waktu 30 menit proses bleaching, penurunan warna lebih besar terjadi pada CPO dari limbah dan campuran CPO mutu tinggi dan mutu rendah dibandingkan $\mathrm{CPO}$ mutu tinggi. Hal ini disebabkan oleh CPO mutu rendah mengandung senyawa pengotor lain dalam jumlah besar berupa suspensi koloid dalam minyak, fosfolipid, karbohidrat dan senyawa kompleks lainnya yang mempengaruhi warna. Senyawa tersebut ikut terserap ke dalam BE dan penyerapannya meningkat dengan meningkatnya waktu bleaching sehingga warna CPO menjadi lebih rendah (menurun).

Tabel 1. Mutu CPO bahan baku

\begin{tabular}{|c|c|c|c|c|c|c|c|c|c|}
\hline \multirow{3}{*}{ Parameter } & \multicolumn{5}{|c|}{ CPO dari TBS 1} & \multirow{3}{*}{$\begin{array}{l}\text { CPO mutu } \\
\text { rendah } \\
\text { dari PKS } 1 \\
\end{array}$} & \multirow{3}{*}{$\begin{array}{c}\text { CPO } \\
\text { dari } \\
\text { TBS } 2 \\
\end{array}$} & \multirow{3}{*}{$\begin{array}{c}\text { CPO } \\
\text { dari } \\
\text { PKS } 2 \\
\end{array}$} & \multirow{3}{*}{$\begin{array}{c}\text { CPO dari } \\
\text { Limbah } \\
\text { PKS } 2 \\
\end{array}$} \\
\hline & \multirow{2}{*}{ Awal } & \multicolumn{2}{|c|}{ Pemanasan } & \multicolumn{2}{|c|}{ Pencampuran } & & & & \\
\hline & & PM 1 & PM 2 & PC 1 & PC 2 & & & & \\
\hline Karoten (ppm) & 550 & 412 & 225 & 442 & 348 & 312 & 767 & 601 & 291 \\
\hline DOBI & 3,9 & 2,5 & 0,65 & 2,92 & 1,52 & 1,4 & 4,8 & 2,68 & 0,85 \\
\hline $\operatorname{ALB}(\%)$ & 4,0 & 5,5 & 6,4 & 5,2 & 7,5 & 7,5 & 3,1 & 5,3 & 21,7 \\
\hline $\operatorname{Air}(\%)$ & 0,22 & 0,2 & 0,1 & 0,22 & 0,23 & 0,23 & 0,24 & 0,02 & 0,26 \\
\hline PV (meq/kg) & 3,4 & 6,7 & 10,3 & 10,4 & 20,6 & 20,5 & 1,2 & 11,9 & 22,9 \\
\hline Warna, 1 inchi $(r / y)$ & $13 / 13$ & $11 / 11$ & $8 / 8$ & $18 / 18$ & $20 / 20$ & $23 / 23$ & $18 / 18$ & $23 / 23$ & $22,9 / 22,9$ \\
\hline
\end{tabular}

Keterangan: PM 1 dan 2 = pemanasan CPO-1 selama 30 dan 60 menit pada suhu $110^{\circ} \mathrm{C}$, PC 1 dan $2=$ Pencampuran antara CPO dari TBS-1 dengan CPO bermutu rendah dengan rasio 60:40 dan 10:90

Tabel 2. Warna CPO (1 inchi, red/yellow) selama waktu pemucatan menggunakan BE $1 \%$ pada $95^{\circ} \mathrm{C}$

\begin{tabular}{|c|c|c|c|c|c|c|c|c|}
\hline \multirow{3}{*}{$\begin{array}{l}\text { Waktu } \\
\text { reaksi } \\
\text { (menit) }\end{array}$} & \multicolumn{5}{|c|}{ CPO dari TBS 1} & \multirow{3}{*}{ CPO dari TBS 2} & \multirow{3}{*}{ CPO dari PKS } & \multirow{3}{*}{$\begin{array}{c}\text { CPO dari } \\
\text { Limbah }\end{array}$} \\
\hline & \multirow{2}{*}{ Awal } & \multicolumn{2}{|c|}{ Pemanasan } & \multicolumn{2}{|c|}{ Pencampuran } & & & \\
\hline & & PM 1 & PM 2 & PC 1 & PC 2 & & & \\
\hline 0 & $13,0 / 13,0$ & $11,0 / 11,0$ & $8,0 / 8,0$ & $18,0 / 18,0$ & $20,0 / 20,0$ & $18,0 / 18,0$ & $23,0 / 23,0$ & $22,9 / 22,9$ \\
\hline 15 & $13,0 / 13,0$ & $11,0 / 11,0$ & $7,2 /, 2$ & $15,0 / 15,0$ & $16,0 / 16,0$ & $17,0 / 17,0$ & $20,6 / 20,6$ & $20,0 / 20,0$ \\
\hline 30 & $12,6 / 12,6$ & $10,3 / 10,3$ & $6,3 / 6,3$ & $15,0 / 15,0$ & $17,0 / 17,0$ & $15,0 / 15,0$ & $20,0 / 20,0$ & $20,0 / 20,0$ \\
\hline 45 & $12,4 / 12,4$ & $10,0 / 10,0$ & $6,0 / 6,0$ & $14,0 / 14,0$ & $16,0 / 16,0$ & $15,0 / 15,0$ & $20,0 / 20,0$ & $18.4 / 18,4$ \\
\hline 60 & $12,0 / 12,0$ & $10,0 / 10,0$ & $6,0 / 6,0$ & $14,0 / 14,0$ & $15,0 / 15,0$ & $14,0 / 14,0$ & $19,8 / 19,8$ & $17,9 / 17,9$ \\
\hline
\end{tabular}

Keterangan: singkatan dapat dilihat pada Tabel 1

Sama halnya dengan variasi waktu bleaching, peningkatan jumlah dosis $\mathrm{BE}$ menyebabkan kadar warna seluruh CPO menurun/semakin rendah (Tabel 3). Fatmayati (2011) menggunakan BE ter-reaktivasi sebanyak 1$5 \%$ dari berat $\mathrm{CPO}$ dan hasil yang diperoleh menunjukkan bahwa jumlah BE dalam pemucatan yang terbaik adalah sebesar 5\%. Nuryanto (2014) juga melaporkan bahwa dosis BE sebanyak 3\% menurunkan warna relatif lebih tinggi dibandingkan dosis 1,5\%. Morad et al. (2006) juga menyatakan hal yang sama bahwa semakin tinggi dosis $\mathrm{BE}$ 
penurunan warna CPO semakin besar disebabkan oleh karoten teradsorpsi. Dosis BE yang optimum akan tergantung pada jumlah dan pengotor alami dalam CPO.

Warna CPO sangat terkait dengan kadar karoten yang dikandungnya. Siahaan et al. (2006) melaporkan bahwa semakin tinggi kadar karoten maka warna CPO semakin merah. Pemanasan CPO menyebabkan senyawa karoten terdegradasi sehingga warnanya menjadi pucat. Penurunan kadar karoten juga terjadi selama proses pemucatan CPO dengan variasi waktu dan dosis BE. Semakin meningkatnya waktu pemucatan dan dosis BE menyebabkan penurunan kadar karoten semakin tinggi (Gambar 1). Penurunan kadar karoten pada CPO dari limbah (DOBI 0,85) relatif lebih rendah dibandingkan sampel lainnya yang disebabkan oleh rendahnya kadar karoten yang dikandungnya (291 ppm). Hal ini menunjukkan bahwa semakin tinggi kadar karoten pada CPO yang dipanaskan menyebabkan degradasi karoten semakin banyak. Fauzi dan Sarmidi (2010) juga melaporkan bahwa senyawa karoten sangat mudah terdegradasi oleh pemanasan.

Selama bleaching, DOBI semakin rendah/menurun dengan meningkatnya waktu pemucatan dan dosis BE (Gambar 2). Penurunan nilai DOBI yang paling besar terjadi pada CPO yang bermutu baik yaitu CPO dari TBS 1 dan 2 (3,9 dan
4,8) dikarenakan kadar karoten relatif lebih tinggi (550 dan 767 ppm) dan produk oksidasi sekundernya relatif rendah. Hasibuan (2016) menyatakan bahwa DOBI memiliki korelasi yang searah dan kuat terhadap kadar karoten. Penurunan DOBI relatif rendah pada CPO bermutu rendah dari limbah (DOBI 0,85) dan campuran CPO dengan mutu rendah (PC 1 dan PC 2) dikarenakan karoten yang dikandungnya relatif rendah masing-masing sebesar 291, 442 dan 348 ppm dan produk oksidasi sekundernya relatif banyak sehingga tidak banyak lagi karoten yang terdegradasi.

Kadar ALB cenderung meningkat dengan meningkatnya waktu bleaching dan dosis BE (Gambar 3). Peningkatan terbesar terjadi pada campuran CPO mutu baik dan mutu rendah. Hal ini disebabkan oleh ALB dapat bersifat autokatalis yang menyebabkan pemercepatan kenaikan ALB saat terjadi pemanasan CPO (Hasibuan dan Ramadona, 2012). Sementara itu, hasil yang berbeda dilaporkan oleh Suryani et al., (2015) bahwa proses bleaching dapat menurunkan kadar ALB namun tidak terlalu signifikan. Perbedaan ini dapat disebabkan oleh jumlah BE yang digunakan berbeda, Suryani et al. (2015) menggunakan BE ter-reaktivasi sebanyak 5\% dan kadar ALB awal dari CPO relatif tinggi, sehingga dengan penggunaan $\mathrm{BE}$ yang besar kemungkinan ALB terserap di dalam BE.

Tabel 3. Warna (1 inchi, red/yellow) CPO pada variasi konsentrasi BE dan pemanasan $95^{\circ} \mathrm{C}$ selama 30 menit

\begin{tabular}{|c|c|c|c|c|c|c|c|c|}
\hline \multirow{3}{*}{$\begin{array}{l}\text { Bleaching } \\
\text { earth (\%) }\end{array}$} & \multicolumn{5}{|c|}{ CPO dari TBS 1} & \multirow{3}{*}{ CPO dari TBS 2} & \multirow{3}{*}{$\begin{array}{l}\text { CPO dari } \\
\text { PKS }\end{array}$} & \multirow{3}{*}{$\begin{array}{c}\text { CPO dari } \\
\text { Limbah }\end{array}$} \\
\hline & \multirow{2}{*}{ Awal } & \multicolumn{2}{|c|}{ Pemanasan } & \multicolumn{2}{|c|}{ Pencampuran } & & & \\
\hline & & PM 1 & PM 2 & PC 1 & PC 2 & & & \\
\hline 0 & $13,0 / 13,0$ & $11,0 / 11,0$ & $8,0 / 8,0$ & $18,0 / 18,0$ & $20,0 / 20,0$ & $18,0 / 18,0$ & $23,0 / 23,0$ & $22,9 / 22,9$ \\
\hline 0,5 & $12,8 / 12,8$ & $10,6 / 10,6$ & $7,0 / 7,0$ & $17,0 / 17,0$ & $16,8 / 16,8$ & $16,5 / 16,5$ & $20,0 / 20,0$ & $20,00 / 20,0$ \\
\hline 1 & $12,5 / 12,5$ & $10,3 / 10,3$ & $6,3 / 6,3$ & $15,0 / 15,0$ & $16,6 / 16,6$ & $15,0 / 15,0$ & $20,0 / 20,0$ & $20,0 / 20,0$ \\
\hline 1,5 & $10,0 / 10,0$ & $8,5 / 8,5$ & $6,0 / 6,0$ & $15,0 / 15,0$ & $15,0 / 15,0$ & $14,0 / 14,0$ & $20,0 / 20,0$ & $18,0 / 18,0$ \\
\hline 2 & $9,0 / 9,0$ & $8,0 / 8,0$ & $5,6 / 5,6$ & $14,0 / 14,0$ & $13,0 / 13,0$ & $14,0 / 14,0$ & $20,0 / 20,0$ & $16,0 / 16,0$ \\
\hline
\end{tabular}

Keterangan: singkatan dapat dilihat pada Tabel 1
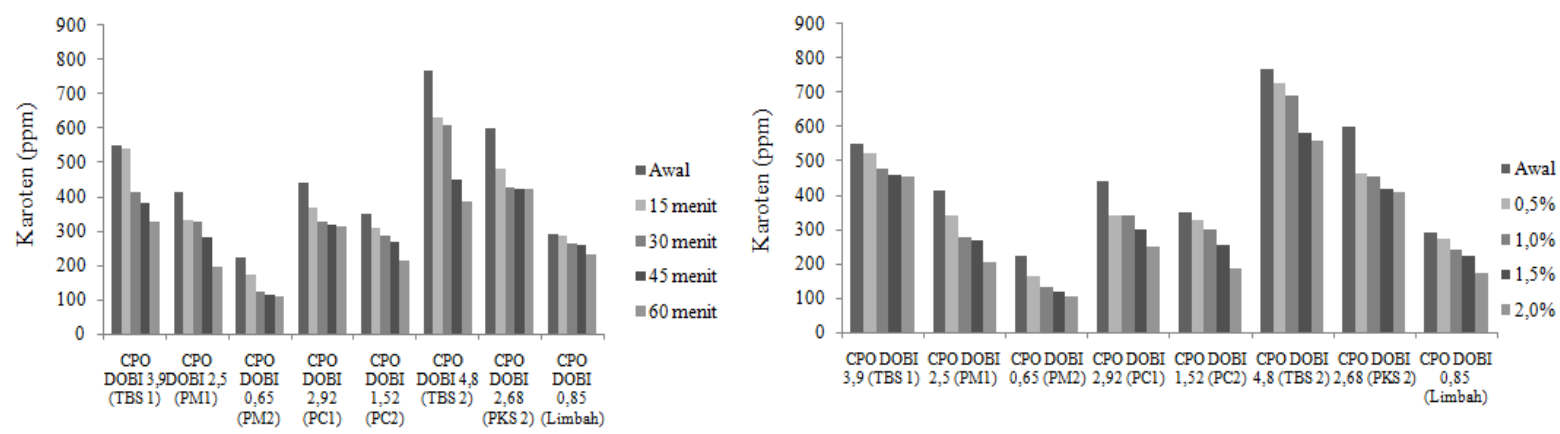

Keterangan: singkatan dapat dilihat pada Tabel 1

Gambar 1. Waktu pemucatan CPO dengan BE 1\% (kiri) dan dosis BE selama 30 menit terhadap karoten 

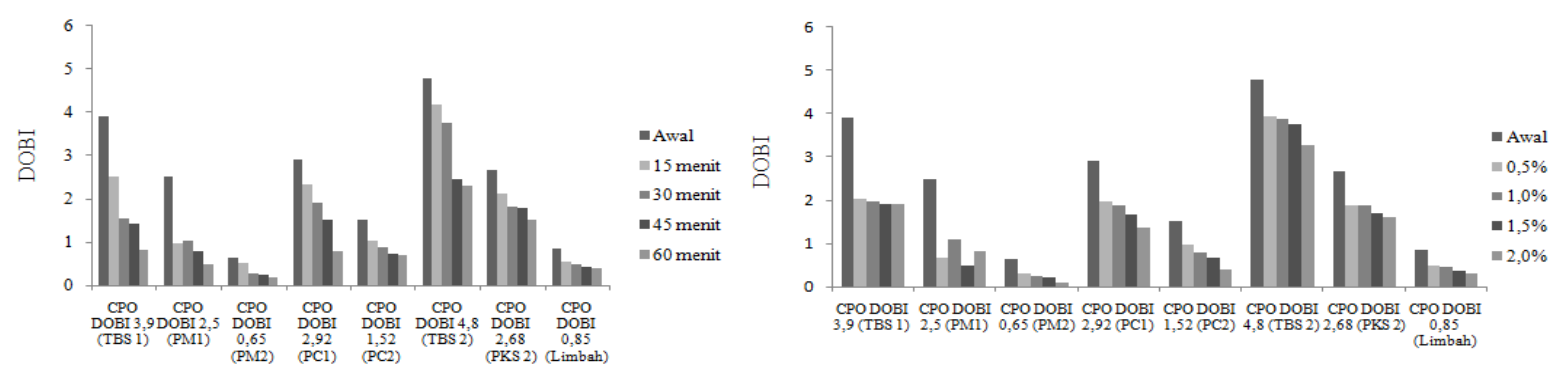

Keterangan: singkatan dapat dilihat pada Tabel 1

Gambar 2. Waktu pemucatan CPO dengan BE 1\% (kiri) dan dosis BE selama 30 menit (kanan) terhadap DOBI
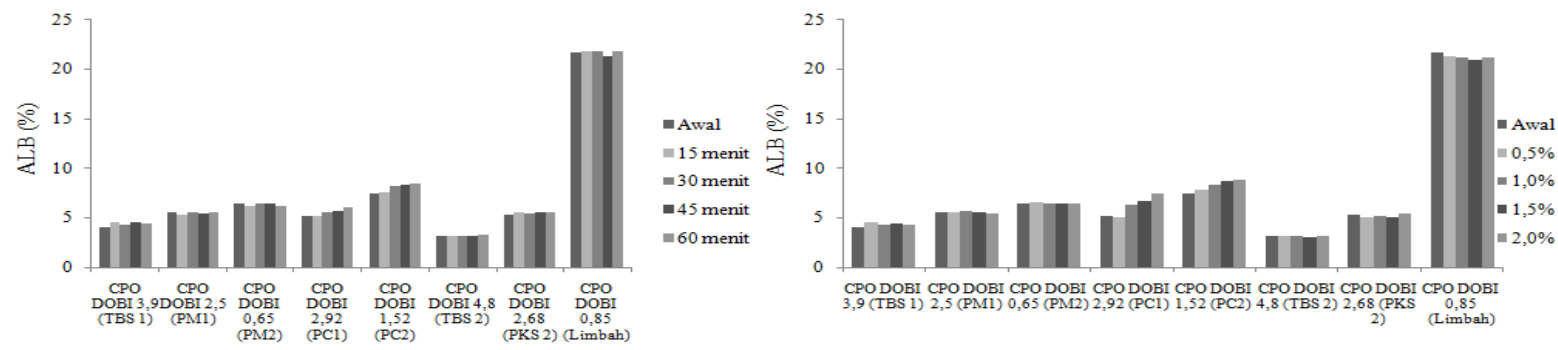

Keterangan: singkatan dapat dilihat pada Tabel 1

Gambar 3. Waktu pemucatan (kiri) dan dosis BE (kanan) terhadap ALB

Ketaren (2008) menyatakan bahwa BE yang digunakan dalam pemucatan akan menyerap suspensi koloid (gum dan resin), ALB serta hasil oksidasi minyak seperti peroksida). Pengaruh waktu pemucatan dan dosis $\mathrm{BE}$ yang digunakan pada proses pemucatan menggunakan bahan baku CPO dengan nilai DOBI 2,92 dan nilai DOBI 1,52 yang dibuat dari campuran $\mathrm{CPO}$ mutu tinggi dan $\mathrm{CPO}$ mutu rendah cenderung meningkatkan ALB dibandingkan dengan bahan baku CPO dengan nilai DOBI rendah yaitu PM 2 (DOBI 0,65) dan CPO limbah (DOBI 0,85). Hal ini menunjukkan bahwa meskipun mutu CPO, khususnya nilai DOBI dapat dimanipulasi dengan cara mencampur CPO mutu tinggi dan mutu rendah, namun dapat berakibat menaikkan nilai ALB selama proses pemucatan yang akan berdampak pada proses deodorisasi lebih lanjut.

Gambar 4 menunjukkan semakin meningkatnya waktu pemucatan dan dosis BE menyebabkan kadar air semakin rendah. Hal ini terjadi karena selama pemucatan CPO dilakukan pemanasan pada suhu $95^{\circ} \mathrm{C}$ yang dapat menyebabkan air menguap. Di samping itu, BE juga menjerap air melalui pori-pori yang dimilikinya sehingga semakin banyak BE, efektivitas penjerapan juga semakin tinggi.

Gambar 4 juga menunjukkan bahwa penurunan kadar air yang dikandung pada CPO dari PKS 2 (DOBI 2,68) relatif rendah baik dengan meningkatnya waktu juga semakin banyaknya dosis BE. Hal ini disebabkan oleh kadar air awal yang dikandung oleh CPO tersebut rendah $(0,02 \%)$ (Tabel 1).

Gambar 5 menunjukkan bahwa bahan baku dengan bilangan peroksida (PV) awal relatif sama yaitu PC 1 dan PM 2, mengalami perubahan nilai PV selama proses pemucatan relatif lebih kecil pada bahan baku PC 1 (CPO dengan DOBI tinggi / 2,92) dibandingkan dengan bahan baku PM 2 (CPO dengan DOBI rendah / 0,65). Dari Gambar 5 juga menunjukkan bahwa PV pada CPO yang dipucatkan cenderung mengalami penurunan hingga waktu 30 menit namun meningkat pada45 menit dan menurun kembali hingga 60 menit. Hal ini disebabkan oleh senyawa peroksida ada yang menguap dan dengan pemanasan yang berlanjut senyawa peroksida terbentuk kembali.

Morad et al. (2006) melaporkan bahwa saat 30 menit proses bleaching, PV menurun namun kemudian meningkat dengan meningkatnya waktu proses. Menurut Frank et al. (2011) bahwa PV dapat terjadi karena oksigen yang reaktif bergabung dengan ikatan rangkap pada asam lemak dalam trigliserida. Selama oksidasi, ikatan rangkap terputus menghasilkan senyawa rantai pendek yang menguap dan residu gliserida teroksidasi. Selain itu, secara keseluruhan sampel CPO menunjukkan bahwa dengan meningkatnya dosis BE, PV menurun. Menurut Ketaren (2008) bahwa BE juga akan menjerap senyawa peroksida. Sehingga semakin banyak jumlah BE maka senyawa peroksida akan semakin banyak terjerap ke dalam BE.Menurut World Health Organization (WHO), PV pada minyak maksimum sebesar $10 \mathrm{meq} / \mathrm{kg}$ (Okonkwo et al., 2012; Amata dan Ozuor, 2014). Minyak yang teroksidasi mengindikasikan tahap awal dari ketengikan (Onwuka dan Akaerue, 2006; Orji and Mbata, 2008; Okonkwo et al., 2012) yang mengandung radikal bebas dan berbahaya bagi kesehatan (Tagoe et al., 2012). 

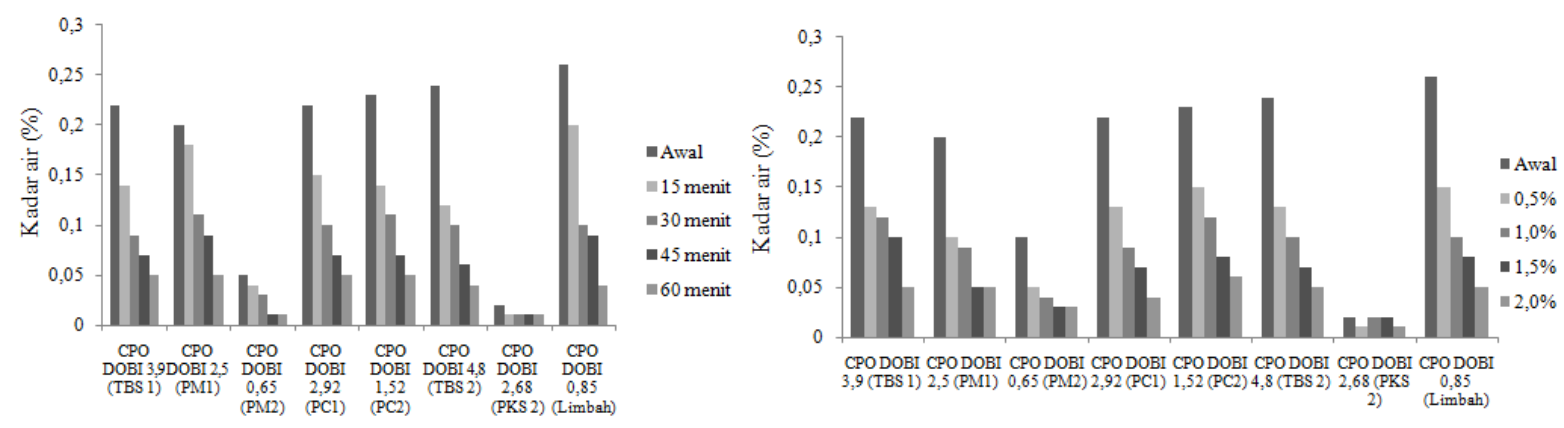

Keterangan: singkatan dapat dilihat pada Tabel 1

Gambar 4. Waktu pemucatan (kiri) dan dosis BE (kanan) terhadap kadar air


Keterangan: singkatan dapat dilihat pada Tabel 1

Gambar 5. Waktu pemucatan (kiri) dan dosis BE (kanan) terhadap bilangan peroksida

\section{KESIMPULAN DAN SARAN}

\section{Kesimpulan}

Pemucatan CPO bervariasi nilai DOBI dipengaruhi oleh dosis bleaching earth (BE) dan waktu proses pemucatan. Semakin tinggi jumlah BE dan lama waktu proses menyebabkan warna CPO semakin pucat, karoten, DOBI dan warna semakin rendah sedangkan ALB semakin meningkat. Pemucatan CPO dari hasil pencampuran CPO mutu tinggi dan CPO mutu rendah dapat meningkatkan ALB, meskipun CPO hasil campuran tersebut memiliki nilai DOBI tinggi, hal ini berdampak pada proses deodorisasi.

\section{Saran}

Untuk menghasilkan CPO berkualitas baik tidak perlu dilakukan proses recycle atau pencampuran antara CPO dari limbah pabrik kelapa sawit ke dalam CPO yang bermutu baik. Hal ini dilakukan agar proses pemucatan CPO menjadi lebih mudah dan biaya relatif lebih rendah karena penggunaan bleaching earth relatif lebih sedikit. Selain itu, perlu dilakukan penelitian lebih lanjut untuk mengetahui proses deodorisasi pada CPO bervariasi DOBI dan mutu lainnya.

\section{DAFTAR PUSTAKA}

Akhmazillah MF, Sarmidi MR, dan Chua LS. 2011. Metabolite profiling of heat treated whole palm oil extract. Asian J Food Agro Indus. 4: 132-140.

Amata IA dan Ozuor E. 2014. The effect of different processing methods on the quality of crude palm oil (CPO) in Delta North Agricultural zone of Delta State, Nigeria. $J$ Environ Issues Agric in Develop Countri. 5(1): 19-24.

Ejikeme EM, Egbuna SO, dan Ejikeme PCN. 2013. Optimal bleaching performance of acid activated 'Ngwulangwu' clay. Int J Eng Innov Technol. 3: 13-19.

Fatmayati. 2011. Pemucatan minyak sawit kasar menggunakan tanah pemucat hasil reaktivasi. [Skripsi]. Bogor: Departemen Teknologi Industri pertanian, Institut Pertanian Bogor.

Fauzi NA dan Sarmidi MR. 2010. Extraction of heat treated palm oil and their stability on betacarotene during storage. J Sci Technol. 45-54.

Frank NEG, Albert MME, Laverdure DEE, Paul K. 2011. Assessment of the quality of crude palm oil from smallholders in Cameroon. J Stored Prod Posthar Res. 2(3): 52-58.

Gibon V, Ayala JV, Dijckmans P, Maes J, Greyt WD. 2009. Future prospects for palm oil refining and modifications. OCL 16. 193200.

Hasibuan HA dan Nuryanto E. 2011. Kajian kandungan $\mathrm{P}, \mathrm{Fe}, \mathrm{Cu}$ dan Ni pada minyak 
sawit, minyak inti sawit dan minyak kelapa selama proses rafinasi. J Stand. 13(1): $45-60$.

Hasibuan HA. 2012. Kajian mutu dan karakteristik minyak sawit indonesia serta produk fraksinasinya. J Stand. 14: 13-21.

Hasibuan HA dan Ramadona. 2012. Monitoring kadar asam lemak bebas (ALB), kadar karoten dan DOBI pada CPO bervariasi ALB selama penyimpanan. Warta Pusat Penel Kelapa Sawit. 17: 87-92.

Hasibuan HA. 2016. Deterioration of bleachability index pada crude palm oil: bahan review dan usulan untuk SNI 01-2901-2006. J Stand. 18(1): 25-34.

Jusoh JM, Rashid NA, dan Omar Z. 2013. Effect of sterilization process on deterioration of bleachability index (DOBI) of crude palm oil (CPO) extracted from different degree of oil palm ripeness. Int J Biosci, Biochem Bioinfor. 3(4): 322-327.

Ketaren S. 2008. Pengantar Minyak dan Lemak Pangan. Jakarta: UI Press.

Morad NA, Aziz MKA, dan Zin RM. 2006. Process Design Degumming and Bleaching of Palm Oil. Research Vote No: 74198. University Teknology Malaysia.

MPOB. 2004. MPOB Test Method: A Compendium of Test on Palm Oil Products, Palm Kernel Products, Fatty Acids, Food Related Products and Others. Malaysia.

Nursulihatimarsyila AW, Cheah KY, Chuah TG, Siew WL, Choong TSY. 2012. Deoiling and regeneration efficiencies of spent bleaching clay. Am J Appl Sci. 7: 434437.

Nuryanto E. 2014. Pengaruh pemanasan spent bleaching earth (SBE) terhadap proses pemucatan CPO. Warta Pusat Penel Kelapa Sawit. 19(3): 128-134.

Okonkwo EU, Arowora KA, Ogundele BA, Omodara MA, Afolayan SS. 2012. Storability and quality indices of palm oil in different packaging containers in Nigeria. J Stored Prod Posthar Res. 3(13): 177-179.
Onwuka GI dan Akaerue BI. 2006. Evaluation of the quality palm oil produce by different methods of processing. Res J Biologic Sci. 1(1-4): 16-19.

Orji MU dan Mbata TI. 2008. Effect of extraction methods on the quality and spoilage of Nigerian palm oil. African Journal of Biochemistry Research. 1(9): 192-196.

Panjaitan FR, Siahaan D, Rivani M, Hasibuan HA. 2009. Perubahan mutu minyak sawit selama proses pengolahan di pabrik kelapa sawit. Prosiding Pertemuan Teknis Kelapa Sawit 2009. Jakarta 28-30 Mei 2009. Hal. 287-294.

Razali MH, Somad A, Halim MA, Roslan S. 2012. A review on crop plant production and ripeness forecasting. Int J Agricul Crop Sci. 4-2: 54-63.

Siahaan D, Johnlennon T, dan Manik M. 2006. Study on carotene content of palm oil in different varieties maturity and unit process in palm oil mill. Proceedings of International Oil Palm Conference 2006 (IOPC 2006). Nusa Dua Bali-Indonesia. June 19-23. 153-158.

Siahaan D, Hasibuan HA, Nuryanto E, Rivani M, Panjaitan FR. 2009. Karakteristik CPO Indonesia. Prosiding Pertemuan Teknis Kelapa Sawit 2009. Jakarta Convention Centre 28 - 30 Mei 2009. Hal 273-280.

Subramaniam V, Menon NR, Sin H, May CY. 2013. The development of a residual oil recovery system to increase the revenue of a palm oil mill. J Oil Palm Res. 25: 116-122.

Suryani A, Pari G, dan Aswad A. 2015. Proses reaktivasi tanah pemucat bekas sebagai adsorben untuk pemurnian minyak sawit kasar dan biodiesel. J Tek Ind Pert. 25(1): 52-67.

Tagoe SMA, Dickinson MJ, dan Appetorgbor MM. 2012. Factors influencing quality of palm oil produced at the cottage industry level in Ghana. Int Food Res J. 19(1): 271-278. 